\title{
HUBUNGAN PENINGKATAN BERAT BADAN DAN PERUBAHAN SIKLUS HAID DENGAN PEMAKAIAN KONTRASEPSI IMPLANT PADA AKSEPTOR KB DI WILAYAH KERJA PUSKESMAS JEUNIEB KABUPATEN BIREUEN
}

\section{Relationship Relationship On Body Increasing And Change Of Haid Cycle With The Use Of Implant Contraception In acceptors in the working areas Jeunieb district bireuen}

\author{
Misrina*1, Rosa Amelia Putri*2 \\ 1. Dosen Akademi Kebidanan Munawarah, Jl. Sultan Iskandar Muda No.18 Kota Juang, Bireuen 24251, Indonesia \\ 2. Mahasiswi Akademi Kebidanan Munawarah, Jl. Sultan Iskandar Muda No.18 Kota Juang, Bireuen 24251, \\ Indonesia
}

*Korespondensi Penulis : misrina517@gmail.com*1

\begin{abstract}
Abstrak
Salah satu Metode Kontrasepsi Jangka Panjang (MKJP) yaitu implant, metode kontrasepsi yang diinsersikan pada bagian subdermal, yang hanya mengandung progestin dengan masa kerja panjang, dosis rendah dan reversible untuk wanita. Efektivitas dari penggunaan kontrasepsi implant ini sangat tinggi. Daya gunanya tinggi dapat dipakai dalam jangka panjang, pengembalian kesuburan cepat kembali dari pengaruh hormon estrogen. Penelitian ini dilakukan untuk mengetahui hubungan peningkatan berat badan dan perubahan siklus haid dengan pemakaian kontrasepsi implant pada akseptor KB di Wilayah Kerja Puskesmas Jeunieb Kabupaten Bireuen.

Populasi dalam penelitian ini adalah seluruh akseptor KB implant yang ada di Wilayah Kerja Puskesmas Jeunieb Kabupaten Bireuen sebanyak 252 jiwa. Teknik pengambilan sampel yang digunakan dalam penelitian ini adalah Cluster Sampling yaitu pengambilan secara kelompok dari populasi sebanyak 61 orang.

Dari hasil penelitian menunjukkan bahwa hasil uji chi square dengan tingkat kepercayaan 95\% $(\alpha=0,05)$ hasil perhitungan menunjukkan nilai $p$ value $(0,014)<\alpha(0,05)$ berarti ha diterima, dan ho ditolak, dengan demikian ada hubungan antara pemakaian kontrasepsi implant dengan peningkatan berat badan. Dari hasil uji chi square dengan tingkat kepercayaan $95 \%(\alpha=0,05)$ hasil perhitungan menunjukkan nilai $p$ value $(0,048)<\alpha(0,05)$ berarti ha diterima, dan ho ditolak, dengan demikian ada hubungan antara pemakaian kontrasepsi implant dengan perubahan siklus haid.

Diharapkan agar responden mau dan aktif mencari informasi tentang KB implant. Selain itu dengan adanya penelitian ini responden tidak perlu cemas dengan gejala efek samping yang ditimbulkan karena pemakaian implant.
\end{abstract}

Kata Kunci : : Berat badan, Siklus haid, KB Implant 
Journal of Healthcare Technology and Medicine Vol. 6 No. 2 Oktober 2020

Universitas Ubudiyah Indonesia

e-ISSN : 2615-109X

\section{ABSTRACT}

One of the long-term contraceptive methods (MKJP) is implants, a subdermal insertion method of contraception, which only contains progestins with a long working life, low dose and is reversible for women. The effectiveness of using contraceptive implants is very high. High usability can be used in the long run, returning fertility quickly back from the influence of the hormone estrogen. This study was conducted to determine the relationship between increased body weight and changes in the menstrual cycle with the use of contraceptive implants in family planning acceptors in the Jeunieb Health Center, Bireuen District.

The population in this study were 252 implant family planning acceptors in the Jeunieb Health Center, Bireuen District. The sampling technique used in this study was cluster sampling, which is group taking from a population of 61 people.

The results showed that the results of the chi square test with a confidence level of $95 \%(\alpha=$ 0.05), the results of the calculation showed that the $p$ value $(0.014)<\alpha(0.05)$ means that ha is accepted, and ho is rejected, thus there is a relationship between use of contraceptive implants with weight gain. From the results of the chi square test with a confidence level of $95 \%(\alpha=0.05)$, the calculation results show that the $p$ value $(0.048)<\alpha(0.05)$ means that ha is accepted, and ho is rejected, thus there is a relationship between the use of implant contraception and menstrual cycle changes.

It is expected that respondents are willing and active in seeking information about implant contraception. In addition, with this study, respondents do not need to worry about the symptoms of side effects caused by using implants.

Keywords: body weight, menstrual cycle, birth control implant

\section{PENDAHULUAN}

Salah satu upaya pemerintah dalam mengendalikan jumlah penduduk adalah dengan melaksanakan program Keluarga Berencana (KB) bagi Pasangan Usia Subur (PUS). Selain mengendalikan jumlah penduduk, program KB juga bermanfaat untuk mewujudkan akses kesehatan reproduksi bagi semua seperti yang tercantum dalam Sustainable Development Goals (SDGs) tujuan 3 yaitu menjamin kehidupan yang sehat dan meningkatkan kesejahteraan penduduk di segala usia dengan indicator meningkatkan Contraceptive Prevalence Rate $(C P R)$. Metode KB hormonal yang paling dominan digunakan oleh peserta KB, sedangkan penggunaan Metode Kontrasepsi Jangka Panjang (MKJP) yang relative masih rendah di kalanganwanita PUS (BKKBN 2011).

Keluarga Berencana $(\mathrm{KB})$ merupakan salah satu pelayanan kesehatan preventif yang paling dasar dan utama bagi wanita. Meskipun tidak selalu diakui demikian, peningkatan dan perluasan pelayanan Keluarga Berencana merupakan salah satu usaha untuk menurunkan angka kesakitan dan kematian ibu yang sedemikian tinggi akibat kehamilan yang dialami oleh wanita. Banyak wanita harus menentukan pilihan kontrasepsi yang sulit, tidak hanya karena 
Journal of Healthcare Technology and Medicine Vol. 6 No. 2 Oktober 2020

Universitas Ubudiyah Indonesia

e-ISSN : 2615-109X

terbatasnya jumlah metode yang tersedia tetapi juga karena metode-metode tertentu mungkin tidak dapat diterima sehubungan dengan kebijakan nasional $\mathrm{KB}$, kesehatan individual dan seksualitas wanita atau biaya untuk memperoleh kontrasepsi (Assalis, 2015).

Upaya untuk mewujudkan keluarga berkualitas, sasaran utamanya adalah terkendalinya pertumbuhan penduduk dan meningkatnya keluarga kecil yang berkualitas, ditandai dengan meningkatnya penggunaan metode kontrasepsi yang rasional, efektif dan efesien (REE). Metoda kontrasepsi yang memenuhi unsur efektif dan efesien adalah metoda kontrasepsi Alat Kontrasepsi Dalam Rahim (AKDR) Intra Uterine Device (IUD), Metode Operasional Wanita (MOW), Metode Operasional Pria (MOP) dan Implan/ susuk, efektif untuk mencegah kehamilan dan biayanya lebih murah, karena sekali membayar pelayanan dapat digunakan dalam waktu yang panjang, sehingga disebut metode kontrasepsi jangka panjang (MKJP) (Hidayat 2017).

Salah satu MKJP yaitu implant, metode kontrasepsi yang diinsersikan pada bagian subdermal, yang hanya mengandung progestin dengan masa kerja panjang, dosis rendah dan reversibel untuk wanita. Efektivitas dari penggunaan kontrasepsi implant ini sangat tinggi. Daya gunanya tinggi dapat dipakai dalam jangka panjang, pengembalian kesuburan cepat bebas dari pengaruh hormon estrogen (Rusmini, 2017).

Obesitas merupakan masalah kesehatan yang sangat serius, apalagi wanita mempunyai risiko lebih besar dibandingkan dengan pria. Pemakaian alat kontrasepsi hormonal masih menjadi pilihan bagi sebagian ibu, sedangkan peningkatan berat badan merupakan efeksampingnya. Oleh karena itu, perlu diteliti kenaikan berat badan pada ibu yang menggunakan alat kontrasepsi hormonal (Rohmahwati, 2017).

Efek dan masalah kesehatan perlu menjadi perhatian bersama. Timbulnya beberapa efek samping dan beberapa masalah kesehatan yang memungkinkan akseptor kontrasepsi implant akan mengalami drop out diantaranya adalah peningkatan berat badan, peningkatan tekanan darah, perubahan siklus haid, Perdarahan bercak dan Sakit kepala. Lebih lanjut dikatakan bahwa umumnya penambahan berat badan dan peningkatan tekanan darah pada wanita yang menggunakan kontrasepsi implant merupakan hal yang paling sering dikeluhkan akseptor kontrasepsi implant. Efek samping pemakaian kontrasepsi implant yaitu peningkatan berat badan yang terjadi terus menerus dapat menyebabkan kegemukan (obesitas). Berat badan yang berlebih atau obesitas meningkatkan risiko relative seorang wanita untuk menderita diabetes mellitus, risiko relative untuk terkena penyakit kardiovaskuler misalnya darah tinggi, selanjutnya dapat meningkatkan factor risiko terjadinya penyakit jantung koroner. Efek 
Journal of Healthcare Technology and Medicine Vol. 6 No. 2 Oktober 2020

Universitas Ubudiyah Indonesia

e-ISSN : 2615-109X

samping dari kontrasepsi implant diantaranya gangguan siklus menstruasi (8,5\%) dan peningkatan berat badan $(3,3 \%)$, peningkatan tekanan darah $(2,2 \%)$, sakit kepala $(5,5 \%)$, dan perdarahan/gangguan siklus haid (1,6\%) (Yuliawati, 2019).

Bertambahnya berat badan pada akseptor KB ini terjadi karena bertambahnya lemak dalam tubuh dan bukan karena retensi cairan tubuh. Berat badan merupakan gambaran jumlah protein, lemak, air, dan mineral pada jaringan tulang. Perubahan berat badan menjadi meningkat atau terjadi peningkatan jika hasil penimbangan berat badan lebih besar dibanding dengan berat sebelumnya. Pertambahan berat badan ini dipengaruhi oleh bertambahnya ukuran berat akibat dari konsumsi makanan yang diubah menjadi lemak selanjutnya disimpan di jaringan bawah kulit (Yuliawati, 2019).

Kontrasepsi implant merupakan alat kontrasepsi yang dipasang dibawah kulit yang mengandung progestin yang dibungkus dalam kapsul silastik silicon polidimetri. Pemasangan kontrasepsi implant ini dipasang minimal 4 minggu pasca persalinan. Alat kontrasepsi implant ini sangat banyak manfaatnya seperti pemakakaian jangka Panjang, kembalinya kesuburan segera setelah pencabutan serta tidak membutuhkan kunjungan ulang seperti KB lainnya. Selain manfaat implant bias menimbulkan perdarahan bercak ringan pada siklus haid dan dapat menyebabkan peningkatan berat badan (Kemenkes RI, 2012).

Menurut BKKBN, pemakaian kontrasepsi implant ini pada banyak klien menyebabkan perubahan pola haid yang berupa bercak/ spotting, hipermenorea, atau meningkatnya jumlah darah haid serta amenorea (BKKBN, 2011).

Dalam upaya menekan laju pertumbuhan manusia, terutama mencegah ledakan penduduk, diperlukan alat kontrasepsi yang menjadi salah satu medianya. Data The Alan Guttmacher Institute, New York menyebutkan di dunia kira-kira 85 dari 100 perempuan yang aktif secara seksual tidak menggunakan metode kontrasepsi apapun (Afsari, 2017).

Badan Kependudukan dan KeluargaBerencana Nasional (BKKBN) memprediksi jumlah penduduk Indonesia berpotensi menjadi terbesar sedunia setelah China dan India jika laju pertumbuhannya tidak bias ditekan secara signifikan jumlah dan pertumbuhan penduduk Indonesia berdasarkan data sensus penduduk tahun 2010 melebihi angka proyeksi nasional yaitu sebesar 237,6 juta jiwa dengan laju pertumbuhan penduduk 1,49 per tahun. Pertumbuhan penduduk yang pesat merupakan akibat dari fertilisasi yang tinggi akan menjadi sumber kemiskinan dan menghambat pertumbuhan ekonomi (BKKBN 2011).

Jumlah Pasangan Usia Subur (PUS) di Indonesia sebesar 38.343 .931 jiwa, yang menggunaan KB aktif 24.258.532 jiwa. Sedangkan data jumlahpemakaian KB implant 
Journal of Healthcare Technology and Medicine Vol. 6 No. 2 Oktober 2020

Universitas Ubudiyah Indonesia

e-ISSN : 2615-109X

sebanyak 1.724.796 jiwa (7,20\%) (Kemenkes RI, 2018).Jumlah Pasangan Usia Subur di Provinsi Aceh sebanyak 369. 141 jiwa, peserta KB modern sebanyak 205.206 (55,59\%). Jumlah yang menggunakan metode kontrasepsi jangka Panjang (MKJP) sebanyak 6,95\%. Jumlah yang menggunakan KB implant sebanyak 6.215 jiwa (Kemenkes RI, 2018).

Berdasarkan data yang diperoleh dari Dinas Kesehatan Kabupaten Bireuen, jumlah PUS sebanyak 80.178 jiwa. Dengan jumlah peserta KB aktif sebanyak 49.126 jiwa (61,3\%). Sedangkan jumlah pemakaian KB implant sebanyak $1.056(2,1 \%)$ jiwa dengan pemakaian terbanyak ada di Wilayah Kerja Puskesmas Jeunieb yaitu sebanyak 234 jiwa (10,2\% (Dinkes Bireuen, 2019).

Berdasarkan data yang diperoleh dari Puskesmas Jeunieb, didapatkan jumlah pemakaian KB implant tahun 2020 sebanyak252. Dari seluruh desa yang ada di Wilayah Kerja Puskesmas Jeuneieb, 10 desa terbanyak pemakai implant antara lain yaitu desa Blang Poroh (10 orang), Meunasah Alue (18 orang), Janggot Seungko (10 orang), Blang Lancang (14 orang), Lhok Kulam (9 orang), Sampo Hajat (9 orang), Lampoh Oe (9 orang), Dayah Baro (9 orang), Teupin Keupula (9 orang) dan Lancang (8 orang) (Puskesmas Jeunieb, 2020).

Dari hasil survey awal yang peneliti lakukan di dua desa terhadap 10 akseptor KB implant, peneliti menanyakan mengenai perubahan gangguan menstruasi sebelum dan sesudah pemakaian KB implant, selain itu peneliti juga menanyakan apakah ada perubahan berat badan selama pemakaian KB implant. 10 akseptor yang diwawancarai, 6 dari mereka mengalami kenaikan berat badan sedangkan 4 ibu lagi tidak mengalami kenaikan berat. Dari 10 akseptor yang diwawancarai menunjukkan bahwa 7 orang mengalami gangguan menstrusi seperti perdarahan haid yang tidak teratur, ada yang haidnya sangat banyak, sementara ke 3 ibu lagi tidak mengalami gangguan mentruasi.

Berdasarkan data diatas, maka peneliti tertarik untuk meneliti tentang"Hubungan peningkatan berat badan dan perubahan siklus haid dengan pemakaian kontrasepsi implant pada akseptor KB di Wilayah Kerja Puskesmas Jeunieb Kabupaten Bireuen Tahun 2020”.

Tujuan Penelitian ini Untuk mengetahui hubungan peningkatan berat badan dan perubahan siklus haid dengan pemakaian kontrasepsi implant pada akseptor KB di Wilayah Kerja Puskesmas Jeunieb Kabupaten Bireuen.

Penelitian ini diharapkan responden tidak perlu cemas dengan gejala efek samping yang ditimbulkan karena pemakaian implant seperti peningkatan berat badan dan perubahan siklus haid karena perubahan ini dapat diatasi. 


\section{METODE PENELITIAN}

Desain penelitian yang digunakan adalah penelitian analitik dengan pendekatan cross sectional, yaitu penelitian yang dilakukan dengan tujuan utama untuk menjawab permasalahan yang sedang dihadapi pada situasi seseorang untuk melihat bagaimana "Hubungan peningkatan berat badan dan perubahan siklus haid dengan pemakaian kontrasepsi implant pada akseptor KB di Wilayah Kerja Puskesmas Jeunieb Kabupaten Bireuen

Penelitian ini telah dilakukan di Wilayah Kerja Puskesmas Jeunieb Kabupaten Bireuen tahun 2020. Penelitian ini telah dilakukan pada bulan Agustus 2020.

Populasi dalam penelitian ini adalah seluruh akseptor KB implant yang ada di Wilayah Kerja Puskesmas Jeunieb Kabupaten Bireuen sebanyak 61 responden.

Teknik pengambilan sampel yang digunakan dalam penelitian ini adalah Cluster Sampling yaitu pengambilan secara kelompok dari populasi.

Jenis data yang digunakan dalam penelitian ini adalah data primer dan data sekunder. Metode pengelohan data collecting, checking, coding, entering dan processing. Analisis data yang digunakan adalah analisis univariat dan analisis bivariat dengan uji chi-square.

\section{HASIL PENELITIAN}

\section{Karakteristik Responden}

Berdasarkan hasil penelitian di Wilayah Kerja Puskesmas Jeunieb Kabupaten Bireuen, terhadap 61 responden yang dilakukan pada bulan Agustus 2020, maka dapat dilihat berbagai macam karakteristik responden, antara lain:

Tabel 1. Distribusi Frekuensi Karakteristik Responden Berdasarkan Umur, Pendidikan, Pekerjaan di Wilayah Kerja Puskesmas Jeunieb Kabupaten Bireuen

\begin{tabular}{ccc}
\hline Karekteristik Responden & Jumlah (n) & Persentase (\%) \\
\hline Umur & 45 & 74 \\
20-35 tahun & 16 & 26 \\
$>35$ tahun & & \\
Pendidikan & 3 & 5 \\
Dasar & 44 & 72 \\
Menengah & 14 & 23 \\
Tinggi & &
\end{tabular}

Pekerjaan 


$\begin{array}{ccc}\text { Bekerja } & 31 & 51 \\ \text { Tidak Bekerja } & 30 & 49\end{array}$

Berdasarkan tabel 1 diketahui dari 61 responden terdapat 45 responden $(74 \%)$ kelompok umur 20-35 tahun, 16 responden (26\%) kelompok 35 tahun. Diketahui pendidikan responden, pendidikan Dasar sebanyak 3 orang (5\%), Pendidikan Menengah sebanyak 44 orang (72\%), pendidikan Tinggi sebanyak14 orang (23\%). Pekerjaan responden Bekerja sebanyak 31 orang (51\%), Tidak Bekerja sebanyak 30 orang $(49 \%)$.

\section{Analisis Bivariat}

Tabel 2. Hubungan Peningkatan Berat Badan dan Perubahan Siklus Haid dengan Pemakaian Kontrasepsi Implant Pada Aseptor KB Implant di Wilayah Kerja Puskesmas Jeunieb Kabupaten Bireuen

\begin{tabular}{|c|c|c|c|c|c|c|c|}
\hline \multirow{3}{*}{$\begin{array}{l}\text { Pemakaian } \\
\text { Kontrasepsi } \\
\text { Implant }\end{array}$} & \multicolumn{4}{|c|}{ Peningkatan Berat Badan } & \multirow{3}{*}{$\begin{array}{c}\sum \\
\mathrm{F}\end{array}$} & \multirow[t]{2}{*}{$\%$} & \multirow[t]{3}{*}{ P-Value } \\
\hline & \multicolumn{2}{|c|}{ Mengalami } & \multicolumn{2}{|c|}{$\begin{array}{c}\text { Tidak } \\
\text { Mengalami }\end{array}$} & & & \\
\hline & $\mathrm{f}$ & $\%$ & $\mathrm{f}$ & $\%$ & & $\%$ & \\
\hline Lama & 25 & 41 & 19 & 31 & 44 & 72 & \\
\hline Baru & 3 & 5 & 14 & 23 & 17 & 28 & 0,014 \\
\hline \multirow{3}{*}{$\begin{array}{l}\text { Pemakaian } \\
\text { Kontrasepsi } \\
\text { Implant }\end{array}$} & \multicolumn{4}{|c|}{ Perubahan Siklus Haid } & $\sum$ & $\%$ & P-Value \\
\hline & \multicolumn{2}{|c|}{ Mengalami } & \multicolumn{2}{|c|}{$\begin{array}{c}\text { Tidak } \\
\text { Mengalami }\end{array}$} & & & \\
\hline & $\mathrm{f}$ & $\%$ & $f$ & $\%$ & $\mathrm{~F}$ & $\%$ & \\
\hline Lama & 36 & 59 & 8 & 13 & 44 & 72 & \\
\hline Baru & 9 & 15 & 8 & 13 & 17 & 28 & 0,048 \\
\hline
\end{tabular}

Analisis Bivariat : Tabel 2 dapat dilihat tabulasi silang berdasarkan peningkatan berat badan dari 61 responden, mayoritas responden yang pemakaian KB implant lama mengalami peningkatan berat badan sebanyak 25 responden $(41 \%)$ dan tidak mengalami peningkatan berat badan sebanyak 19 responden (31\%). Sedangkan responden yang baru memakai KB implant yang mengalami peningkatan berat badan sebanyak 3 responden $(5 \%)$ dan yang tidak mengalami peningkatan berat badan sebanyak 14 responden (23\%).

Dari hasil uji chi square dengan tingkat kepercayaan 95\% $(\alpha=0,05)$ hasil perhitungan menunjukkan nilai $\mathrm{p}$ value $(0,014)<\alpha(0,05)$ berarti Ha diterima dan Ho ditolak, dengan demikian ada hubungan antara pemakaian kontrasepsi implant dengan peningkatan berat badan.

Berdasarkan uji silang diatas perubahan siklus haid dari 61 responden, mayoritas responden yang lama memakai KB implant mengalami perubahan siklus haid sebanyak 36 
Journal of Healthcare Technology and Medicine Vol. 6 No. 2 Oktober 2020

Universitas Ubudiyah Indonesia

e-ISSN : 2615-109X

responden (59\%) dan tidak mengalami perubahan siklus haid sebanyak 8 responden (13\%). Sedangkan responden yang baru memakai KB implant mengalami perubahan siklus haid sebanyak 9 responden (15\%) dan tidak mengalami perubahan siklus haid sebanyak 8 responden $(13 \%)$.

Dari hasil uji chi square dengan tingkat kepercayaan 95\% $(\alpha=0,05)$ hasil perhitungan menunjukkan nilai $\mathrm{p}$ value $(0,048)<\alpha(0,05)$ berarti Ha diterima dan Ho ditolak, dengan demikian ada hubungan antara pemakaian kontrasepsi implant dengan perubahan siklus haid.

\section{PEMBAHASAN}

\section{Hubungan peningkatan berat badan dengan pemakaian kontrasepsi implant}

Berdasarkan uji silang, mayoritas responden yang pemakaian KB implant lama mengalami peningkatan berat badan sebanyak 25 responden $(41 \%)$ dan tidak mengalami peningkatan berat badan sebanyak 19 responden (31\%). Sedangkan responden yang baru memakai KB implant yang mengalami peningkatan berat badan sebanyak 3 responden (5\%) dan yang tidak mengalami peningkatan berat badan sebanyak 14 responden (23\%).

Dari hasil uji chi square dengan tingkat kepercayaan 95\% $(\alpha=0,05)$ hasil perhitungan menunjukkan nilai p value $(0,014)<\alpha(0,05)$ berarti Ha diterima dan Ho ditolak, dengan demikian ada hubungan antara pemakaian kontrasepsi implant dengan peningkatan berat badan.

Teori juga menunjukkan adanya efek samping peningkatan berat badan yang terjadi terus menerus dapat menyebabkan kegemukan (obesitas). Berat badan yang berlebih atau obesitas meningkatkan risiko relative seorang wanita untuk menderita diabetes mellitus, risiko relative untuk terkena penyakit kardiovaskuler misalnya darah tinggi, selanjutnya dapat meningkatkan factor risiko terjadinya penyakit jantung coroner (Sinau, 2010 dikutip dari Yuliawati, 2019).

Bagi akseptor implant, misalnya setiap sebulan sekali melakukan penimbangan berat badan yang bisa dilakukan bersamaan dengan kegiatan Posyandu, untuk lebih ditekankan, hal untuk bisa mendeteksi secara dini terjadinya kenaikan berat badan. Bagi akseptor yang mengalami kenaikan berat badan perlu diberi pengertian akan pentingnya melakukan berbagai aktifitas fisik yang memadai, dan melakukan olah raga secara teratur, agar peningkatan berat badan ini tidak berlanjut pada kondisi obesitas, yang dapat berdampak pada terjadinya gangguan kesehatannya (Setio, 2010 Dikutip dari Yuliawati, 2019). 
Journal of Healthcare Technology and Medicine Vol. 6 No. 2 Oktober 2020

Universitas Ubudiyah Indonesia

e-ISSN : 2615-109X

Hasil penelitian yang dilakukan oleh Yuliawati (2019), dengan judul "Pengaruh Penggunaan Kontrasepsi Implant Terhadap Peningkatan Berat Badan Dan Hypertensi di Kabupaten Lampung Timur" menunjukkan Analisis data menggunakan chi-square test. Hasil penelitian menunjukkan penggunaan kontrasepsi implant berpengaruh terhadap peningkatan berat badan $(\mathrm{p}=0,013 ; \mathrm{OR}=1,932)$ dan terhadap peningkatan tekanan darah atau hipertensi $(\mathrm{p}=0,024$; OR: 1,897 .

Asumsi peneliti, adanya hubungan antara peningkatan berat badan dengan pemakaian $\mathrm{KB}$ implant dikarenakan mayoritas responden memakai KB implant dalam waktu lama (> 12 bulan), tubuh masih beradaptasi dengan KB implant tersebut. Sebagian dari responden mengatakan bahwa awalnya selama pemakaian KB implant berat badan meningkat, namun mereka mengatur pola diet serta porsi makan sehari-hari untuk mencegah peningkatan berat badan yang dapat membuat mereka tidak nyaman.

\section{Hubungan perubahan siklus haid dengan pemakaian kontrasepsi implant}

Berdasarkan uji silang, mayoritas responden yang lama memakai KB implant mengalami perubahan siklus haid sebanyak 36 responden (59\%) dan tidak mengalami perubahan siklus haid sebanyak 8 responden (13\%). Sedangkan responden yang baru memakai KB implant mengalami perubahan siklus haid sebanyak 9 responden (15\%) dan tidak mengalami perubahan siklus haid sebanyak 8 responden (13\%).

Dari hasil uji chi square dengan tingkat kepercayaan 95\% $(\alpha=0,05)$ hasil perhitungan menunjukkan nilai $\mathrm{p}$ value $(0,048)<\alpha(0,05)$ berarti Ha diterima dan Ho ditolak, dengan demikian ada hubungan antara pemakaian kontrasepsi implant dengan perubahan siklus haid.

Hal ini sejalan dengan teori yang dikeluarkan oleh Hartanto 2010 yang dikutip dari Rahayu (2017) yang mengatakan bahwa efek samping Implant paling utama adalah perubahan pola haid, yang terjadi pada kira-kira 60\% akseptor dalam tahun pertama setelah insersi. Yang paling sering terjadi adalah bertambahnya hari-hari perdarahan dalam siklus, perdarahan-bercak (spotting), berkurangnya panjang siklus haid, amenore meskipun lebih jarang terjadi dibandingkan perdarahan lama atau perdarahan bercak. Dalam pengguna jangka panjang implant dapat menimbulkan kekeringan pada vagina, gangguan emosi, nevorsitas dan jerawat. Dari hasil penelitian dari lama pemakaian KB Implan $\leq 1$ tahun banyak yang mengalami soptting yang dikategorikan selalu, sering dan jarang. Ini membuktikan bahwa hormone dalam tubuh sangat mempengaruhi gangguan menstruasi. Kadar FSH yang tinggi dapat mengakibatkan terjadinya stimulasi ovarium yang berlebihan (hiperstimulasi) sehingga dijumpai kadar estrogen yang sangat tinggi. Pada awal pemakaian ini terjadi karena ketidak 
Journal of Healthcare Technology and Medicine Vol. 6 No. 2 Oktober 2020

Universitas Ubudiyah Indonesia

e-ISSN : 2615-109X

seimbangan hormone sehingga endometrium mengalami histologi. Dan yang tidak mengalami spotting ini dikarenakan hormone dalam tubuh seimbang sehingga endometrium tidak histologi.

Hasil penelitian yang dilakukan oleh Rahayu (2017) dengan judul "Hubungan Lama Pemakaian KB Implant dengan Siklus Menstruasi di Wilayah Kerja Puskesmas Rowosari 02 Kabupaten Kendal" menunjukkan Analisa hasil penelitian dari 33 rersponden mayoritas responden yang menggunakan KB Implan kurang dari 12 bulan yaitu sebanyak 20 responden $(60,6 \%)$, dan minoritas responden yang menggunakan KB Implant lebih dari 12 bulan sebanyak 13 responden $(39,4 \%)$. Mayoritas responden yang siklus menstrusinya teratur yaitu sebanyak 18 akseptor (54,5\%), dan minoritas responden yang siklus menstruasinya tidak teratur sebanyak 15 akseptor (45,5\%). Analisa bivariat dihasilkan ada hubungan antara lama pemakaian KB Imlant dengan keteraturan siklus menstruasi $(\rho=0,005 \leq 0,05)$.

Asumsi peneliti adanya hubungan antara perubahan siklus haid dengan pemakaian KB implant dikarenakan efek samping dari pemakaian KB implant yaitu menyebabkan siklus haid yang tidak teratur. Efek sampingnya beragam ada yang pola yang tidak teratur, perubahan siklus haid, perdarahan dan keluhan lainnya yang berhubungan dengan pola haid. Penyebab perubahan siklus haid yang terjadi selama pemakaian $\mathrm{KB}$ implant karena kandungan hormonal yang terdapat dalam kapsul implant.

\section{KESIMPULAN}

Berdasarkan hasil penelitian maka dapat disimpulkan sebagai berikut: Ada hubungan antara pemakaian kontrasepsi implant dengan peningkatan berat badan yang ditunjukkan nilai $\mathrm{p}$ value $(0,014)<\alpha(0,05)$. Ada hubungan antara pemakaian kontrasepsi implant dengan perubahan siklus haid yang ditunjukkan nilai $p$ value $(0,048)<\alpha(0,05)$.

\section{SARAN}

Diharapkan kepada responden agar mau dan aktif mencari informasi tentang KB implant. Selain itu dengan adanya penelitian ini responden tidak perlu cemas dengan gejala efek samping yang ditimbulkan karena pemakaian kontrasepsi implant.

\section{DAFTAR PUSTAKA}

Afsari. (2017). Faktor Yang Mempengaruhi Akseptor KB Dalam Memilih Kontrasepsi Di Puskesmas Jumpandang Baru Makassar. Jurnal Kesehatan : Universitas Islam Alaudin Makasar 
Journal of Healthcare Technology and Medicine Vol. 6 No. 2 Oktober 2020

Universitas Ubudiyah Indonesia

e-ISSN : 2615-109X

Assalis. (2015). Hubungan Sosial Budaya Dengan Pemilihan Metode Kontrasepsi. Jurnal Kesehatan : Universitas Malahayati Lampung

Ardayani. (2017). Konsep Dasar Implant. Jakarta : Direktorat Kesehatan Reproduksi.

BKKBN. (2011). Buku Panduan Praktis Pelayana Kontrasepsi. Jakarta. Direktorat Kesehatan Reproduksi.

. (2014). KB Pasca Persalinan dan PascaKeguguran. Jakarta. BKKBN.

Hidayat. (2017). Determinan Penggunaan Metode Kontrasepsi Jangka Panjang (MKJP) pada

Akseptor KB. Jurnal Kesehatan Masyarakat : Universitas Negeri Semarang.

Iman. M. (2015). Panduan Penyusunan Karya Tulis Ilmiah Bidan Kesehatan. Medan : Cita Pusaka.

. (2016). Pengukuran Variabel dengan SPSS. Medan : Cita Pusaka.

Kemenkes RI. (2012). Pedoman Pelayanan Keluarga Berencana Pasca Persalinan di

Fasilitas Kesehatan. Jakarta : Direktorat Kesehatan Reproduksi. . (2018). Profil Kesehatan Indonesia http://kemenkes.go.id.

Meilani, S. 2010. Pelayanan Keluarga Berencana. Yogjakarta: Fitramaya.

Rahayu. (2017). Hubungan Lama Pemakaian KB Implan Dengan Siklus Menstruasi di Wilayah Kerja Puskesmas Rowosari 02 Kabupaten Kendal. Jurnal Kesehatan : Universitas Muhammadiyah.

Rusmini. (2017). Pelayanan KB dan Kesehatan Reproduksi. Jakarta: Trans Info Media.

Rohmawati. (2017). Hubungan Lama Pemakaian Kontrasepsi Implant dengan Kenaikan Berat Badan. Jurnal Kesehatan: Universitas Muhammadiyah.

Sari. (2017). Faktor-Faktor Yang Mempengaruhi Rendahnya Pemilihan Alat Kontrasepsi MKJP Pada PUS di Puskesmas Tembilahan Hulu. Jurnal Kesehatan.

Yuliawati. (2017). Pengaruh Penggunaan Kontrasepsi Implant Terhadap Peningkatan Berat Badan Dan Hypertensi Di Kabupaten Lampung Timur. Jurnal Kesehatan: Universitas Muhammadiyah. 